\section{(6)}

\section{OPEN ACCESS}

'Department of Medicina Interna, Centro Hospitalar São João, Porto, Porto, Portugal ${ }^{2}$ Radiology Department, Centro Hospitalar de Sao Joao, Porto, Porto, Portugal

${ }^{3}$ Intensive Care Unit, Centro Hospitalar de Sao Joao, Porto, Porto, Portugal

\section{Correspondence to} Dr Carolina Ourique, cso.ourique@gmail.com

Accepted 29 January 2017

\title{
Unusual course of a haematoma of the thigh
}

\author{
Carolina Ourique, ${ }^{1}$ Francisco Rego-Costa, ${ }^{2}$ Paulo Torres-Ramalho ${ }^{3}$
}

\section{DESCRIPTION}

A Caucasian woman aged 56 years presented to emergency room (ER) department with leucorrhoea and fever since 48 hours. She was a smoker, had no diabetes history, no prosthetic material and denied use of injected drugs.

A month before, the patient had a closed inguinal trauma due to fall from height with a muscle strain of the anterior right thigh. Despite rest and analgesics, she went to ER several times because of progressive local pain and swelling. After 3 weeks, a local ultrasound scan showed a $3 \mathrm{~cm}$ size haematoma associated with probable rupture of obturator internus and rectus femoris muscles. On the following days, she developed fetid leucorrhoea associated with movements and compression of the anterior thigh. On physical examination and analyses, she had sepsis criteria and the abdomen/pelvic CT scan (figure1A, B) and MRI (figure1C, D) showed an abscess of $105 \times 25 \mathrm{~mm}$ size, complicated with osteomyelitis of the femur and fistulisation to the vagina through obturador foramen. The patient was treated with empiric large-spectrum antibiotics (piperacillin/ tazobactam and linezolid) and surgical drainage with soft-tissue debridement was performed. Anaerobic agents and a Streptococcus specimen were found on the exudate material. Blood cultures and HIV test were negative. One month has passed and the patient is clinically and radiologically improving. The antimicrobial therapy will be maintained according to her medical course.

In this patient, the gradual symptoms and the closed trauma misled the physicians, leading to delay of the diagnosis. The acute osteomyelitis was secondary to a contiguous spread of the infected haematoma and, as expected in these cases, polymicrobial population was identified. ${ }^{1}$ The extension of the infection with fistulisation is an unusual feature in a patient with no immunosuppressive condition.

\section{Learning points}

- Delay in the diagnosis of soft tissue infection can lead to catastrophic consequences, such as contiguous spread of infection to bone and fistulisation, even in immunocompetent patients.

- Since the key of successful management of osteomyelitis is early diagnosis, physicians must keep high suspicion in patients with persistent pain after trauma.

- Acute osteomyelitis may respond to antibiotics alone and the duration of treatment should be guided by clinical evolution.
To cite: Ourique C, RegoCosta F, Torres-Ramalho P. BMJ Case Rep Published online: [please include Day Month Year] doi:10.1136/ bcr-2017-219204

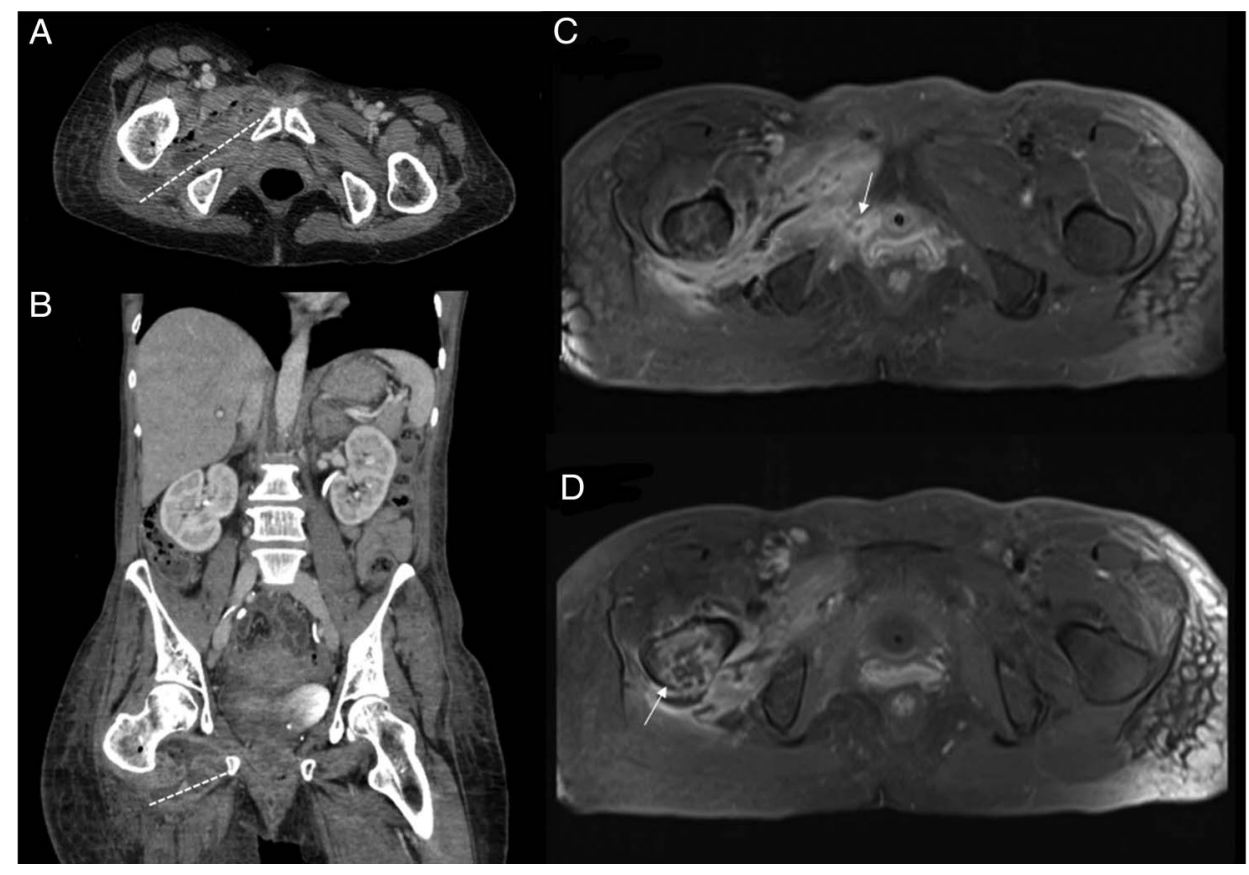

Figure 1 Abdominal and pelvic CT scan, axial (A) and coronal (B) views, showing a multilobulated heterogeneous abscess of the right thigh containing gas, with $105 \times 25 \times 52 \mathrm{~mm}$ size (intermittent white line). (C and D) Magnetic resonance axial T1-weighted postgadolinium images revealing the abscess of the right thigh with fistulae to vagina (C, white arrow) and signs of osteomyelitis of the right greater trochanter and femoral head ( $D$, white arrow). 


\section{Images in...}

Twitter Follow Carolina Ourique @Carolina Ourique

Contributors $\mathrm{CO}$ and FR-C made the diagnosis. All authors were involved in management of the patient, wrote the manuscript and performed the literature research. PTR corrected the manuscript and gave conceptual advice. All authors read and approved the final version of the manuscript.

Competing interests None declared.

Patient consent Obtained.

Provenance and peer review Not commissioned; externally peer reviewed.
Open Access This is an Open Access article distributed in accordance with the Creative Commons Attribution Non Commercial (CC BY-NC 4.0) license, which permits others to distribute, remix, adapt, build upon this work non-commercially, and license their derivative works on different terms, provided the original work is properly cited and the use is non-commercial. See: http://creativecommons.org/ licenses/by-nc/4.0/

\section{REFERENCE}

1 Lew DP, Waldvogel FA. Osteomyelitis. Lancet 2004;364:369-79.

Copyright 2017 BMJ Publishing Group. All rights reserved. For permission to reuse any of this content visit http://group.bmj.com/group/rights-licensing/permissions.

BMJ Case Report Fellows may re-use this article for personal use and teaching without any further permission.

Become a Fellow of BMJ Case Reports today and you can:

- Submit as many cases as you like

- Enjoy fast sympathetic peer review and rapid publication of accepted articles

- Access all the published articles

- Re-use any of the published material for personal use and teaching without further permission

For information on Institutional Fellowships contact consortiasales@bmjgroup.com

Visit casereports.bmj.com for more articles like this and to become a Fellow 